\title{
Retinoic Acid Response Element
}

National Cancer Institute

\section{Source}

National Cancer Institute. Retinoic Acid Response Element. NCI Thesaurus. Code C13634.

A cis-acting transcription regulatory element. It is bound by the retinoic acid receptors. 